\title{
Does business education cultivate environmental citizenship?
}

\author{
RiyaAdh Lillah \& Suzette Viviers
}

\begin{abstract}
Reductive management theories (based on the utility maximisation economic model) are increasingly being criticised as the cause of recent corporate scandals. Management education has neglected the interwovenness of humans and the environment, and the moral obligation of businesses towards the natural environment. This study identified perceptions of students and academics at a prominent South African university regarding levels of environmental awareness and values, implications of environmental management, environmental education, pro-environmental behaviours, and incentives to go green, using a questionnaire. The results revealed that business students and academics differ from their counterparts in other faculties regarding perceptions of factors that influence environmentally responsible citizenship.
\end{abstract}

Keywords: ecological ethics; environmental education; environmental values; incentives; natural environment; utility maximisation

\author{
Riyaadh Lillah \\ NMMU Business School \\ Nelson Mandela Metropolitan University \\ 20 Bird Street \\ Port Elizabeth \\ 6031 \\ South Africa \\ T: +27415044701 \\ F: +27415832644 \\ E: riyaadh.lillah@nmmu.ac.za
}

\section{Suzette Viviers*}

Department of Business Management

University of Stellenbosch Private Bag X1

Matieland, Stellenbosch

South Africa

7602

T: +27218082223

F: +27218082226

E: sviviers@sun.ac.za

* Author to whom correspondence should be addressed

\section{INTRODUCTION}

The recent spate of corporate scandals (involving corporate practices which, together with other factors, culminated in the 2008 financial crisis) has resulted in mounting criticism of the ethical integrity of management practices in for-profit organisations. This, in turn, has resulted in calls for a reorientation of management education, which, at present, exposes students to the economic model of utility maximisation (Goshal, 2005). An article published in this journal in 2009 echoed this sentiment by proclaiming that business education erodes the character of management students (Elegido, 2009).

Although Elegido does not explicitly point out exactly what he means by character, he implies that character refers to how the individual understands and conducts him/herself within the

Riyaadh Lillah is the Research Co-ordinator for the Nelson Mandela Metropolitan University (NMMU) Business School. His research interests include the environmental management in public and private organisations, including universities. Currently, his attention is focused on the greening of business curricula, with the aim of preparing business graduates who are able to operate effectively in the low-carbon economy of the future. He has also been instrumental in the establishment of a 'green student movement' at NMMU.

Suzette Viviers is a Professor in the Department of Business Management at Stellenbosch University. She teaches mainly financial and investment management, and serves on the Research Ethics Committee of the university. Her research interests centre on responsible investing and various topics in the fields of business and environmental ethics. 
broader context of society. Thus, it could be said that his focus is on the broadly ethical manner in which individuals understand and interact with one another. Elegido (2009:16) further argues that commonly used economic and social models of human behaviour are highly reductive, and that "business schools fail to acquaint their students with broader and more inclusive views of human nature."

In recent times, consideration for the natural environment has become more widely publicised, and has emerged as an important aspect of human existence. Furthermore, climate change has been identified as one of the greatest challenges faced by humanity, and, more specifically, for present purposes, businesses ${ }^{1}$ (World Wildlife Fund, 2008). Scientific consensus, reflected in reports of the Intergovernmental Panel on Climate Change (IPCC), is that the earth is indeed warming, mainly due to greenhouse gas emissions from human activity (IPCC $4^{\text {th }}$ Assessment Report, 2007) ${ }^{2}$. The consequences of climate change threaten the survival of many plant and animal species, as well as food and water security, creating an increased potential for conflict as a result of resource scarcity. However, the IPCC only published peer-reviewed empirical research until June 2006. Since then, a significant body of peer-reviewed empirical research has been published that shows that the assumptions made in the 2007 IPCC report were too conservative, and that observed climate change is, in fact, occurring at a more rapid pace than previously thought (World Energy Outlook, 2008; Romm, 2008). Leading scientists worldwide are calling for an immediate and dramatic reduction in greenhouse gas emissions by 2020 , in order to limit the effects of climate change.

Direct implications of climate change for South Africa (some of which have already been observed) include temperature rises above the global average, an increase in flooding in the eastern part of the country, and a rise in sea level (State of the environment, 2010). It therefore follows that no one, including business managers, can afford to ignore the causal link between human society and nature today.
Because it is impossible to detach economic endeavours from imminent ecological limits, it has to be admitted that business ethics and, more specifically, business education, cannot isolate itself from ethical matters pertaining to the natural environment. A discipline that takes a more encompassing approach to understanding the complex relationship between humans and their social and natural environments is ecological ethics. Curry (2007) points out that the more common term environmental ethics presupposes a dualism between human beings and non-human nature - an assumption that centres on human interests. Because the word ecology treats humans and biota as integral parts of ecological systems, the phrase ecological ethics is less presumptuous and more accurate, as it affirms the interdependence of humans and nature (Kovel, 2002:10). Curry (2007) remarks that ethics is not something "optional," something to be addressed, after one's needs, both physical and financial, have been met. Rather, ethics cuts directly to the core of all human activity.

There is also something ancient about an ecological ethic. Keller (2008) states that, "prior to Abrahamic monotheism and Greek rationalism, ancient peoples, particularly nomadic huntergatherers, probably considered themselves as integral parts of what encompassed them, moving with herds, in concert with meteorological and seasonal changes, seeing themselves as one kind amongst other living beings." They probably did not see themselves apart from the environment, as modern society has learned to do - with conspicuously detrimental effects on the integrity of natural ecosystems (Berry, 1996). Innovations of the industrial revolution further distanced us from the natural world, and technological comfort has come at the expense of the awareness of our responsibilities as environmental citizens (Keller, 2008).

\section{PROBLEM STATEMENT}

Assuming that a shift towards environmentally responsible citizenship reflects a change from a self-centred axiological approach on the part 
of individuals to one of greater awareness of their interconnectedness with the rest of society and its natural surroundings, the purpose of this study was to investigate whether signs of such a shift could be detected among students and academics. Specific attention was given to the following: environmental awareness and values, the implications of environmental management, environmental education, and proenvironmental behaviours. The research was undertaken in recognition of the increasingly important role that universities ought to play in addressing the challenges posed by humaninduced environmental degradation.

Although the researchers acknowledge that many factors other than education can influence the development of character, this article will focus on education as a key determinant in creating an environmentally responsible citizenry. Several researchers (e.g., Armstrong \& Impara, 1991; Hawthorne \& Alabaster, 1999; Cordano et al., 2003, and Short, 2010:7) found that environmental education interventions have a significant impact on promoting pro-environmental behaviour.

This article will present selected findings from an online survey that aimed to assess the perceptions of students and academics at a South African university toward greening the university. The term green should be read as implying the promotion of a set of values and behaviours that are compatible with the assumption that the interests of individuals and the natural environment coincide. For higher education institutions, this means re-orientating the teaching, research, engagement, and operations of the university towards an increasing awareness of the need to consider and act upon the interwovenness of humanity and nature.

\section{RESEARCH QUESTIONS AND OBJECTIVES}

Given the problem investigated, this study focussed on the following questions:

- Are there differences between the environmental awareness and values of students and academics of the Business and Economic Sciences (BES) faculty and those of respondents in other faculties?

- What are the perceptions of students and academics toward the implications of environmental management? Are BES students and academics more, or less, convinced of the benefits of environmental management than their peers in other faculties?

- How much importance do students and academics attach to integrating green topics into existing modules, especially those registered and working in the BES faculty?

- To what extent do students and academics engage in green initiatives on campus? Are BES students and staff more, or less, engaged in pro-environmental behaviours?

- Which incentives are likely to motivate students and academics to engage in environmentally friendly activities whilst on campus? Are students and academics in the BES faculty more, or less, motivated by incentives to go green than respondents in other faculties?

In addressing these questions, the following research objectives were formulated:

- To conduct an in-depth literature review on ecological ethics, environmental citizenship, environmental awareness and values, the implications of environmental management, environmental education, and proenvironmental behaviours;

- To develop a research instrument to investigate the environmental perceptions and behaviours of students and academics;

- To collect and analyse primary quantitative data by means of appropriate statistical procedures; and

- To draw pertinent conclusions and provide recommendations to decision-makers at higher education institutions, particularly those in BES faculties. 


\section{RESEARCH DESIGN AND METHODOLOGY}

In this study, a positivistic research paradigm was adopted. Two survey questionnaires (one each for students and academics) were developed, based on literature and consultations with environmental experts at two South African universities. Each questionnaire consisted of six sections requesting the biographical details of the respondents, as well as their perceptions of a range of environmental issues. In this article, only statistics relating to students' and academics' environmental awareness and values, their perceptions of the implications of environmental management, their desire to learn about green topics, the pro-environmental behaviours in which students and academics engage, and the incentives that could motivate them to engage in more pro-environmental behaviours will be reported and commented on.

Descriptive and inferential statistics were calculated, using Statistica version 9. Statistical significance was measured at the 5\% confidence level.

\section{SAMPLE DESCRIPTION}

The biographical details of students and academics are presented in Tables 1 and 2 .

TABle 1: SAmple Description - Students

\begin{tabular}{|c|c|c|c|c|c|}
\hline & & \multicolumn{2}{|c|}{ All faculties } & \multicolumn{2}{|c|}{ BES } \\
\hline & & $\mathbf{N}$ & $\%$ & $\mathbf{N}$ & $\%$ \\
\hline \multirow[t]{3}{*}{ Gender } & Male & 147 & 45.9 & 49 & 49.5 \\
\hline & Female & 179 & 54.1 & 50 & 50.5 \\
\hline & Total & 326 & 100.0 & 99 & 100.0 \\
\hline \multirow{3}{*}{$\begin{array}{l}\text { Level of } \\
\text { study }\end{array}$} & Undergraduate & 259 & 79.4 & 86 & 86.9 \\
\hline & Postgraduate & 67 & 20.6 & 13 & 13.4 \\
\hline & $\underline{\text { Total }}$ & 326 & 100.0 & 99 & 100.0 \\
\hline \multirow[t]{8}{*}{ Faculty } & Arts & 51 & 15.5 & $\mathrm{~N} / \mathrm{A}$ & $\mathrm{N} / \mathrm{A}$ \\
\hline & $\begin{array}{l}\text { Business and } \\
\text { economic } \\
\text { sciences (BES) }\end{array}$ & 99 & 30.4 & $\mathrm{~N} / \mathrm{A}$ & $\mathrm{N} / \mathrm{A}$ \\
\hline & Education & 13 & 4.0 & $\mathrm{~N} / \mathrm{A}$ & $\mathrm{N} / \mathrm{A}$ \\
\hline & $\begin{array}{l}\text { Engineering, } \\
\text { the built } \\
\text { environment } \\
\text { and IT }\end{array}$ & 52 & 16.0 & $\mathrm{~N} / \mathrm{A}$ & $\mathrm{N} / \mathrm{A}$ \\
\hline & Health science & 29 & 8.9 & $\mathrm{~N} / \mathrm{A}$ & $\mathrm{N} / \mathrm{A}$ \\
\hline & Law & 10 & 3.1 & $\mathrm{~N} / \mathrm{A}$ & $\mathrm{N} / \mathrm{A}$ \\
\hline & $\underline{\text { Science }}$ & 72 & 22.1 & $\mathrm{~N} / \mathrm{A}$ & $\mathrm{N} / \mathrm{A}$ \\
\hline & Total & 326 & 100.0 & & \\
\hline
\end{tabular}

TABle 2: SAMPle Description - ACADEMics

\begin{tabular}{|c|c|c|c|c|c|}
\hline & \multicolumn{2}{|c|}{ All faculties } & \multicolumn{2}{|c|}{ BES } \\
\hline & & $\mathbf{N}$ & $\%$ & $\mathbf{N}$ & $\%$ \\
\hline \multirow[t]{3}{*}{ Gender } & Male & 106 & 42.1 & 15 & 48.4 \\
\hline & Female & 146 & 57.9 & 16 & 51.6 \\
\hline & Total & 252 & 100.0 & 31 & 100.0 \\
\hline \multirow[t]{4}{*}{ Age } & $22-30$ years & 41 & 16.3 & 8 & 25.8 \\
\hline & $31-40$ years & 60 & 23.8 & 9 & 29.0 \\
\hline & $\begin{array}{l}\text { Older than } 40 \\
\text { years }\end{array}$ & 151 & 59.9 & 14 & 45.2 \\
\hline & Total & 252 & 100.0 & 31 & 100.0 \\
\hline \multirow{3}{*}{$\begin{array}{l}\text { Job } \\
\text { description }\end{array}$} & Academic & 126 & 50.00 & 25 & 80.6 \\
\hline & $\begin{array}{l}\text { Administrative } \\
\text { / Support / } \\
\text { Technical }\end{array}$ & 126 & 50.00 & 6 & 19.4 \\
\hline & $\underline{\text { Total }}$ & 252 & 100.0 & 31 & 100.0 \\
\hline \multirow[t]{8}{*}{ Faculty } & Arts & 20 & 15.9 & $\mathrm{~N} / \mathrm{A}$ & $\mathrm{N} / \mathrm{A}$ \\
\hline & $\begin{array}{l}\text { Business and } \\
\text { economic sciences } \\
\text { (BES) }\end{array}$ & 25 & 19.8 & $\mathrm{~N} / \mathrm{A}$ & $\mathrm{N} / \mathrm{A}$ \\
\hline & Education & 9 & 7.1 & $\mathrm{~N} / \mathrm{A}$ & $\mathrm{N} / \mathrm{A}$ \\
\hline & $\begin{array}{l}\text { Engineering, } \\
\text { the built } \\
\text { environment, } \\
\text { and IT }\end{array}$ & 15 & 11.9 & $\mathrm{~N} / \mathrm{A}$ & $\mathrm{N} / \mathrm{A}$ \\
\hline & Health sciences & 15 & 11.9 & $\mathrm{~N} / \mathrm{A}$ & $\mathrm{N} / \mathrm{A}$ \\
\hline & Law & 3 & 2.4 & $\mathrm{~N} / \mathrm{A}$ & $\mathrm{N} / \mathrm{A}$ \\
\hline & Science & 39 & 31.0 & $\mathrm{~N} / \mathrm{A}$ & $\mathrm{N} / \mathrm{A}$ \\
\hline & Total & 126 & 100.0 & & \\
\hline
\end{tabular}

As indicated in Table 1, the majority of students who participated in the survey were female (54.1\%). Most students were enrolled for undergraduate qualifications (79.4\%), particularly in the BES faculty (30.4\%). Of the academics (Table 2 ), most respondents (57.9\%) were female. Close to one fifth of the academics responding to the survey $(19.8 \%)$ were employed in the BES faculty. The profile of these respondents, however, differs from the overall sample, in that they tended to be younger than the other academics in the sample.

\section{LITERATURE REVIEW}

\section{Ecological ethics}

According to Minteer and Collins (2008), ecological ethics as a field reflects respect for both the complexity of environmental problems and the capacity of citizens, ethicists, and scientists to address those problems, while examining the underlying values that may be in conflict. One could add that, because ecology implies the interconnectedness of living beings and inorganic things, ecological ethics appropriately takes such 
interconnectedness into consideration (Kovel, 2002:14).

Curry (2007) distinguishes between degrees of non-anthropocentrism by referring to shades of green. These shades range from light green (shallow anthropocentrism), through medium green (the extension of traditional humanorientated moral philosophy to non-humans), to the dark green ethics of ecocentrism.

According to Keller (2008), the devaluation of non-human nature is the principal problem in Western culture, and Curry (2007) argues that the origin of this problem can be traced back to the process of modernisation. Keller (2008) suggests that the core cause of the current environmental crisis relates to the conception of nature as a machine - the essential attribute of modernity that precipitated today's deleterious ecological consequences. Modern society tends to see the universe as a superlatively exquisite machine, created by God, and designed to operate according to the mathematical laws of physics (Heisenberg, 1958). Thus, according to Foster and Burkett (2000), the foundation of the modern view of nature is one of mechanistic materialism (mechanism), the view which is advocated by Bacon, Galileo, Harvey, Hobbes, Descartes, Newton, and others.

In short, modernism in science and philosophy (before Darwin) holds that nature is material, and operates mechanically according to strict causal laws; that all natural phenomena can be described in terms of inert matter in motion, and that nature is devoid of inherent value or purpose.

The practical outcome of the mechanistic view of nature has been the utilisation of environmental systems for economic ends (Bernstein, 1981). Thus, the only value non-human biota have is use-value for humans. The mechanistic view of nature leads directly to an economic theory that non-human nature is "a set of inert raw resources to be mastered and exploited by human reason" (Curry, 2007). Environmental and ecological philosophy must address the metaphysical and axiological failures of the mechanistic view of nature, in order to lay a new foundation for an inclusive human perspective on ecological systems; that is, one that acknowledges humanity's intimate involvement in these systems. This would entail recognition that the traditional anthropocentric value system has to be replaced by one that is ecocentric. On an individual level and in practical terms, a shift towards an ecocentric value system can be seen as a shift towards environmental citizenship.

\section{Environmental citizenship}

According to Dobson (2010:6), environmental citizenship can be loosely defined as "proenvironmental behaviour, in public and in private, driven by a belief in fairness of the distribution of environmental goods, in participation, and in the co-creation of sustainability policy."

MacGregor and Szerszynski (2003) offer a slightly different definition of environmental citizenship. These authors characterise environmental citizenship as a personal desire to learn more about the environment and to take responsible environmental action, encouraging individuals, communities, and organisations to consider environmental rights and duties, and being concerned about the earth.

Hawthorne and Alabaster (1999) developed and tested a model dealing with the factors that influence environmental citizenship. Their model included the following factors: environmental information, awareness, concern, attitudes/ beliefs, education and training, knowledge, skills, literacy, and responsible behaviour. Some significant influencing factors identified were: the desire to act, ability to act, desire to learn, environmental literacy, environmental concern, and environmental education and training. In line with Hawthorne and Alabaster's reasoning, this study gave specific attention to students' and academics' environmental awareness and values, their perceptions of the implication of environmental management, their desire to engage in environmental education (whether to learn or to teach), their engagement in proenvironmental behaviours, and incentives that could motivate them to engage in proenvironmental behaviours. 


\section{Environmental awareness and values}

The $21^{\text {st }}$ century has seen a surge of environmental awareness and concern amongst the general public (Roberts, Kivilu \& Davids, 2010:195), as well as for-profit organisations (MIT Sloan Management Review \& The Boston Consulting Group, 2011). Most of the frameworks or guiding principles for environmental education (such as the Belgrade Charter of 1975 and the Tbilisi Declaration of 1977) view an environmental awareness as the first step to creating an environmentally responsible citizenry. Moody and Hartel (2007) state that any environmentally responsible student (business, or other) should have a basic awareness and understanding of how the earth works as a physical system, recognise the relationship between the natural environment and human impacts thereon, and have an appreciation for the complexity of these interactions.

Venkataraman (2008) claims that, as citizens become increasingly aware of environmental problems, the challenge for environmental education remains to promote a sense of responsibility and environmental stewardship. While awareness of environmental issues does indeed play a pivotal role, it does not guarantee action. He argues that "much still remains to be done to find the most effective ways to teach about the environment and impart personal responsibility and action."

Dietz, Fitzgerald, and Shwom (2005) define values as principles that aid in decision-making when preferences are in conflict. These authors also define values in economic terms, as a guide when making decisions among different alternatives, according to a utilitarian ethic (the greatest good for the greatest number of people). According to Onkila (2008), environmental values are contained within axiological universalism. In this approach, motivational content is described as the understanding, appreciation, tolerance, and protection of all human beings and nature.

If the implications of the preceding considerations for university education are taken into account, it seems clear that a greater awareness of human impacts on the environment and the consequences thereof can be fostered among students, by integrating green topics (emphasising the interconnectedness of humans and nature) into existing modules.

The South African Department of Environmental Affairs (2010:29) reported that, although more attention has been given to environmental knowledge in higher education curricula, this attempt has been "ad hoc, small scale, dependent on lecturer interest, uneven across the education and training system, and appears to be inadequate" to create an environmentally responsible citizenry.

Maduna (2010:1) analysed the prospectuses of BES faculties and business schools at 23 South African higher education institutions to gain insight into the types of environmentally-orientated modules and qualifications being offered. Of the 38 existing modules and qualifications offered in 2010, 14 were short courses, 12 were electives, eight were compulsory modules, and four were full qualifications. Most of these (47\%) were offered at postgraduate level, 29 percent were lifelong learning programmes, and 24 percent were undergraduate modules and qualifications. The most prevalent topics addressed included environmental economics (34\%), followed by environmental management (29\%), and environmental law (11\%). Only three modules included elements of ecological ethics. Thus, it would seem that ecological ethics modules that could create a greater awareness of green issues and cultivate environmental values have been neglected by BES faculties and business schools in South Africa.

\section{Implications of environmental management}

For the purpose of this research, environmental management was defined as the actions of individuals to protect the quality and continuity of life through the conservation of natural resources and the prevention of pollution (Newton, 2005:3; Lesourd \& Schilizzi, 2001:36). The benefits of environmental management for private and public enterprises (including universities) include 
(Darnall et al., 2006; Millet, 2005:5; Sammalisto \& Arvidsson, 2005; Sadgrove, 1997:123):

- a reduction in environmental and associated risks;

- improved legal compliance;

- continuous improvement in processes and cost reduction, leading to increased efficiency and profits;

- satisfaction of customer needs for green products and services;

- improved reputation, which can be an important marketing tool to gain competitive advantage;

- improved employee morale; and

- complete transparency.

Given these benefits, especially increased profits, it could be said that directors of companies have a fiduciary duty towards shareholders to implement sound environmental management systems. In the spirit of promoting transparency, all companies listed on the Johannesburg Stock Exchange have, since 2010, been required to produce integrated reports that reflect, not only the company's financial position, but also its social and environmental impact (Integrated Reporting Committee, 2011). Part of implementing an environmental management system (EMS) is creating a document trail of all activities related to the EMS. As such, an EMS could assist in generating integrated reports now required of listed companies, which, in turn, will ensure legal compliance and transparency in terms of an organisation's environmental impact.

A key element of an EMS is the requirement for an organisation's major stakeholders (students and academics, in the case of a higher education institution) to receive relevant training, which provides an important vehicle for changing individual and organisational behaviours toward the environment (Thomas, 2004:37). Ferrar (2008) reaffirms this assertion by stating that organisations responding to the challenge of climate change will create a demand for professionals who can operate in a low-carbon economy, and, thus, also for environmental education.

\section{Environmental education}

According to Loubser (2005:45), environmental education is inseparable from human considerations of social, economic, political, and ecological factors. The Belgrade Charter, adopted at the United Nations's Educational, Scientific and Cultural Organization (UNESCO) workshop held in Yugoslavia in 1975, characterises environmental education as a participatory process that has the potential to develop individuals who have the knowledge, skills, motivation, and commitment to take action, both individually and collectively, to address current and prevent future environmental issues.

Cortese (2003) and others (such as Uhl and Anderson (2001), Wright (2002), and Zietsman and Pretorius (2006)) highlight the critical role that higher education institutions should play in preparing present and future generations to effectively deal with a warming planet. As public institutions, higher education institutions can meet their obligation to support sustainable societies by incorporating sound environmental management principles into their teaching and research endeavours, engaging with stakeholders, and taking the lead in terms of greening their own operations. This all-encompassing approach should create an atmosphere in which environmental education can flourish and equip students with the environmental knowledge, skills, and values that society needs for real progress in striving for a low-carbon economy. According to Sherren (2006), two approaches exist to incorporating sustainability topics into tertiary qualifications. Firstly, all qualifications (however specialised) should produce environmentally literate graduates. and, secondly, environmental specialists should be produced. In this study, the relative importance of various green topics that should be integrated into existing modules will be investigated. 


\section{Pro-environmental behaviours}

Most definitions of environmental education and environmental citizenry refer to some form of behaviour, action, or active participation that is aimed at protecting the natural environment. In fact, Short (2010:9) states that participation in environmental protection is inherent in the goals of environmental education as prescribed by the Tbilisi Conference Declaration (1977). As environmental citizenry is seen as the intended outcome of environmental education (Hawthorne \& Alabaster, 1999:26), it can be argued that pro-environmental behaviours are a reflection of the degree to which individuals prescribe to environmental citizenship. De Groot and Steg (2008:330) state that pro-environmental behaviours refer to any actions taken to protect and conserve the environment for all living creatures (human and non-human) in a personal and professional capacity.

Monroe (2003) distinguishes between five categories of environmental behaviours, namely environmental activism, non-activist political behaviours, consumer behaviours, ecosystem behaviours, and behaviours specific to individual expertise or a workplace. Examples for each of Monroe's different categories of environmental behaviours are provided in Table 3 .

Table 3: Five categories of enVironmental BEHAVIOURS

\begin{tabular}{|c|c|c|}
\hline & $\begin{array}{l}\text { Category of } \\
\text { behaviour }\end{array}$ & Examples of behaviours \\
\hline 1 & $\begin{array}{l}\text { Environmental } \\
\text { activism }\end{array}$ & $\begin{array}{l}\text { Actively participating in, } \\
\text { or leading, environmental } \\
\text { initiatives. }\end{array}$ \\
\hline 2 & $\begin{array}{l}\text { Non-activist } \\
\text { political } \\
\text { behaviours }\end{array}$ & $\begin{array}{l}\text { Joining an organisation, voting } \\
\text { for pro-environmental political } \\
\text { parties, signing a petition, or } \\
\text { writing a cheque. }\end{array}$ \\
\hline 3 & $\begin{array}{l}\text { Consumer } \\
\text { behaviours }\end{array}$ & $\begin{array}{l}\text { Purchasing green products, } \\
\text { recycling, reducing energy } \\
\text { use, altering consumption and } \\
\text { investment decisions, etc. }\end{array}$ \\
\hline 4 & $\begin{array}{l}\text { Ecosystem } \\
\text { behaviours }\end{array}$ & $\begin{array}{l}\text { Building bird boxes, planting } \\
\text { sea oats, counting wildlife } \\
\text { populations, promoting the use } \\
\text { of fire breaks, etc. }\end{array}$ \\
\hline 5 & $\begin{array}{l}\text { Behaviours } \\
\text { specific to } \\
\text { individual } \\
\text { expertise or } \\
\text { workplace }\end{array}$ & $\begin{array}{l}\text { Reducing waste in the production } \\
\text { process, establishing mortgage } \\
\text { criteria for energy-efficient } \\
\text { houses, suing a polluter, etc. }\end{array}$ \\
\hline
\end{tabular}

Source: Adapted from Monroe (2003)
A different approach to categorising proenvironmental behaviours is to distinguish between intent-orientated and impact-orientated behaviours (Poortinga et al., 2004:75). Intentorientated behaviours are driven by individuals' environmental concern, and are pursued regardless of its impact on the environment. In contrast, impact-orientated behaviours are undertaken based on the direct impact of such behaviours on the environment. Gatersleben et al. (2002:335) found that environmental values influence intent-orientated behaviours, while socio-demographic variables, such as age and household income, are related to impactorientated behaviours.

\section{RESEARCH HYPOTHESES}

Based on the literature review and the premise that BES students and academics might differ from students and academics in other faculties, two sets of null hypotheses were formulated and tested in this study.

$\mathrm{H}_{0,1}:$ There is no difference between BES students and students in other faculties in terms of:

$\mathrm{H}_{0,1.1}$ : their awareness of their impact on the natural environment;

$\mathrm{H}_{0,1.2}$ : the environmental values they exhibit;

$\mathrm{H}_{0,13.3}$ : their perceptions of the implications of environmental management;

$\mathrm{H}_{0,1.4}$ : their desire to learn about environmental topics in their modules;

$\mathrm{H}_{0,1.5}$ : the extent to which they engage in proenvironmental behaviours; and

$\mathrm{H}_{0,1.6}$ : the incentives that could motivate them to engage in pro-environmental behaviours.

$\mathrm{H}_{0,2}$ : There is no difference between BES academics and academics in other faculties in terms of:

$\mathrm{H}_{0,2.1}$ : their awareness of their impact on the natural environment;

$\mathrm{H}_{0,2.2}$ : the environmental values they exhibit;

$\mathrm{H}_{0,2.3}$ : their perceptions of the implications of environmental management; 
$\mathrm{H}_{0,2.4}$ : their desire to incorporate environmental topics in their modules;

$\mathrm{H}_{0,2.5}:$ the extent to which they engage in proenvironmental behaviours; and

$\mathrm{H}_{0,2.6}$ : the incentives that could motivate them to engage in pro-environmental behaviours.

\section{EMPIRICAL FINDINGS - STUDENTS}

\section{Environmental awareness and values}

Statements in this section of the questionnaire gauged students' perceptions on a five-point Likert scale, where 1 represented strongly disagree and 5 represented strongly agree. Appropriate statistical tests were used to test the hypotheses.

Table 4 contains descriptive and inferential statistics on the level of green awareness among students, as well as the environmental values they exhibit. Statements are ranked from the highest to the lowest mean scores for respondents in the BES faculty.
According to the results in Table 4, all students had a relatively high level of awareness of their impact on the natural environment. Although not statistically significant, it should be noted that BES students were slightly less aware of their environmental impact.

As shown in Table 4, students in the BES faculty viewed only two statements dealing with environmental values as important (mean scores ${ }^{3}$ 4.2), whereas students in the other faculties viewed all five statements reflecting green values as very important. The mean scores for BES students were consistently lower than those of students in other faculties. All five mean scores were statistically significant. Business students seem to exhibit less respect for plant and animal life, as well as less concern about the protection and preservation of non-human nature.

Based on these findings, $\mathrm{H}_{0,1.1}$ dealing with the environmental awareness of BES students cannot be rejected; however, $\mathrm{H}_{0,1.2}$ dealing with the environmental values exhibited by students can be rejected. This finding is in line with the argument that business education erodes character to a

TABLE 4: EnVironmental AWAREnEss AND VAlues - STUdents

\begin{tabular}{|c|c|c|c|c|c|c|c|c|c|c|}
\hline \multirow{2}{*}{ Code } & \multirow{2}{*}{ Statement } & \multicolumn{2}{|c|}{ Mean } & \multicolumn{2}{|c|}{$\begin{array}{r}\text { Standard } \\
\text { deviation }\end{array}$} & \multicolumn{2}{|c|}{ Valid N } & \multirow{2}{*}{ df } & \multirow{2}{*}{ t } & \multirow{2}{*}{ value $^{(a)}$} \\
\hline & & $\begin{array}{l}\text { Other } \\
\text { faculties }\end{array}$ & BES & $\begin{array}{c}\text { Other } \\
\text { faculties }\end{array}$ & BES & $\begin{array}{l}\text { Other } \\
\text { faculties }\end{array}$ & BES & & & \\
\hline $\begin{array}{l}\text { Environmental } \\
\text { values } 1\left(\mathrm{H}_{0,1.2}\right)\end{array}$ & $\begin{array}{l}\text { I respect all plant life on the } \\
\text { campus where I study. }\end{array}$ & 4.6 & 4.3 & 0.70 & 0.91 & 225 & 96 & 319 & 3.345 & $0.001^{*}$ \\
\hline $\begin{array}{l}\text { Environmental } \\
\text { values } 2\left(\mathrm{H}_{0,1.2}\right)\end{array}$ & $\begin{array}{l}\text { The protection of the } \\
\text { natural environment on the } \\
\text { campus where I study is } \\
\text { important to me. }\end{array}$ & 4.6 & 4.3 & 0.76 & 0.89 & 226 & 99 & 323 & 2.907 & $0.004^{*}$ \\
\hline $\begin{array}{l}\text { Environmental } \\
\text { values } 3\left(\mathrm{H}_{0,1.2}\right)\end{array}$ & $\begin{array}{l}\text { I respect all animal life on } \\
\text { the campus where I study. }\end{array}$ & 4.5 & 4.2 & 0.90 & 1.07 & 226 & 99 & 323 & 2.508 & $0.013^{*}$ \\
\hline $\begin{array}{l}\text { Environmental } \\
\text { values } 4\left(\mathrm{H}_{0,1.2}\right)\end{array}$ & $\begin{array}{l}\text { It is important to me } \\
\text { that plant biodiversity be } \\
\text { maintained on the campus } \\
\text { where I study. }\end{array}$ & 4.4 & 4.0 & 0.96 & 1.04 & 226 & 99 & 323 & 3.096 & $0.002^{*}$ \\
\hline $\begin{array}{l}\text { Awareness of } \\
\text { environmental } \\
\text { impact } 1\left(\mathrm{H}_{0,1.1}\right)\end{array}$ & $\begin{array}{l}\text { I have an impact on the } \\
\text { natural environment of the } \\
\text { campus where I study. }\end{array}$ & 4.0 & 3.8 & 1.12 & 1.14 & 227 & 99 & 324 & 1.613 & 0.108 \\
\hline $\begin{array}{l}\text { Environmental } \\
\text { Values } 5\left(\mathrm{H}_{0,1.2}\right)\end{array}$ & $\begin{array}{l}\text { It is important to me that } \\
\text { animal biodiversity be } \\
\text { maintained on the campus } \\
\text { where I study. }\end{array}$ & 4.3 & 3.8 & 1.01 & 1.24 & 226 & 97 & 321 & 3.408 & 0.001 * \\
\hline $\begin{array}{l}\text { Awareness of } \\
\text { environmental } \\
\text { impact } 2\left(\mathrm{H}_{0,1.1}\right)\end{array}$ & $\begin{array}{l}\text { I have become more aware } \\
\text { of my impact on the natural } \\
\text { environment on the campus } \\
\text { where I study within the } \\
\text { past } 12 \text { months. }\end{array}$ & 3.4 & 3.2 & 1.26 & 1.23 & 227 & 98 & 323 & 0.809 & 0.419 \\
\hline
\end{tabular}

(a) An * indicates statistical significance at the 95\% confidence level 
large extent, where character is understood as specified in ethical and value-orientated terms pertaining to the interdependence of society and the natural environment. The researchers are aware of the fact that character development depends on more than just education. However, research has shown that educational intervention not only has lasting positive effects on environmental perceptions and behaviours (Hsu, 2004:37; Johnson \& Manoli, 2008:115), but also enhances some of the other influencing factors of environmental citizenship, such as locus of control, environmental responsibility, intention to act, and perceived ability to act (Armstrong \& Impara, 1991; Hawthorne \& Alabaster, 1999; Cordano et al., 2003; Short, 2010).

\section{Implications of environmental management}

Four statements were formulated to gauge students' views on the implications of greening the university. As indicated earlier, literature suggests that sound environmental management could lead to improved reputation and cost savings for a university something that is of primary importance in the long term. Students' views on this topic are shown in Table 5.
As illustrated in Table 5, BES students had consistently lower mean scores than students from other faculties. Students in other faculties viewed the reputation of the university as a leader in the field of sound environmental management in South Africa as more important than students in the BES faculty did. The difference between the groups was, however, not statistically significant. A statistically significant difference was observed in the perceptions of students in the BES faculty and other students on the question of whether green initiatives will save the university money. Students in the BES faculty were not as convinced as their counterparts in other faculties that this would be the case. Based on these findings, $\mathrm{H}_{0,1.3}$ can be rejected.

\section{Environmental education}

Students were requested to indicate the degree of importance they attach to the integration of several green topics into existing modules (See Table 6). In this study, the degree of importance that students attach to the incorporation of green topics into existing module was assumed to represent their desire to learn about the topic. As mentioned earlier, Hawthorne and Alabaster

TABLE 5: IMPlications OF ENVIRONMENTAL MANAGEMENT - STUDENTS

\begin{tabular}{|c|c|c|c|c|c|c|c|c|c|c|}
\hline \multirow{2}{*}{ Code } & \multirow{2}{*}{ Statement } & \multicolumn{2}{|c|}{ Means } & \multicolumn{2}{|c|}{$\begin{array}{l}\text { Standard } \\
\text { deviation }\end{array}$} & \multicolumn{2}{|c|}{ Valid N } & \multirow{2}{*}{ df } & \multirow{2}{*}{$\begin{array}{c}\mathrm{t} \\
\text { value }\end{array}$} & \multirow{2}{*}{$\begin{array}{c}\mathbf{P} \\
\text { value(a) }\end{array}$} \\
\hline & & $\begin{array}{c}\text { Other } \\
\text { faculties }\end{array}$ & BES & $\begin{array}{c}\text { Other } \\
\text { faculties }\end{array}$ & BES & $\begin{array}{c}\text { Other } \\
\text { faculties }\end{array}$ & BES & & & \\
\hline $\begin{array}{l}\text { Environmental } \\
\text { implications } 1 \\
\left(\mathrm{H}_{0,1.3}\right)\end{array}$ & $\begin{array}{l}\text { It is important to me that } \\
\text { my university becomes } \\
\text { a pioneer in the field } \\
\text { of good environmental } \\
\text { management among } \\
\text { organisations in South } \\
\text { Africa. }\end{array}$ & 4.5 & 4.4 & 0.78 & 0.82 & 226 & 99 & 323 & 1.498 & 0.135 \\
\hline $\begin{array}{l}\text { Environmental } \\
\text { implications } 2 \\
\left(\mathrm{H}_{0,1.3}\right)\end{array}$ & $\begin{array}{l}\text { It is important to me that } \\
\text { my university becomes } \\
\text { a pioneer in the field } \\
\text { of good environmental } \\
\text { management among } \\
\text { South African } \\
\text { universities. }\end{array}$ & 4.5 & 4.4 & 0.82 & 0.82 & 225 & 99 & 322 & 1.142 & 0.255 \\
\hline $\begin{array}{l}\text { Environmental } \\
\text { implications } 3 \\
\left(\mathrm{H}_{0,1.3}\right)\end{array}$ & $\begin{array}{l}\text { Green initiatives will save } \\
\text { the university money. }\end{array}$ & 3.8 & 3.4 & 1.07 & 1.17 & 225 & 97 & 320 & 2.796 & $0.006^{*}$ \\
\hline $\begin{array}{l}\text { Environmental } \\
\text { implications } 4 \\
\left(\mathrm{H}_{0,1.3}\right) \\
\end{array}$ & $\begin{array}{l}\text { Green initiatives will } \\
\text { not be too expensive to } \\
\text { implement. }\end{array}$ & 3.6 & 3.4 & 1.07 & 0.95 & 225 & 99 & 322 & 1.008 & 0.314 \\
\hline
\end{tabular}

(a) An * indicates statistical significance at the $95 \%$ confidence level 
TABLE 6: SignificANT DIFFERENCES IN STUDENTS' PERCEPTIONS OF ENVIRONMENTAL EDUCATION, ACCORDING TO FACULTY

\begin{tabular}{|c|c|c|c|c|c|c|c|c|c|c|c|}
\hline \multirow[b]{2}{*}{ Code } & \multirow[b]{2}{*}{$\begin{array}{c}\text { It will be } \\
\text { valuable if } \\
\text { a topic such } \\
\text { as__can be } \\
\text { incorporated } \\
\text { into an } \\
\text { EXISTING } \\
\text { module. }\end{array}$} & \multicolumn{8}{|c|}{ Faculty - mean scores } & \multirow[b]{2}{*}{$\begin{array}{c}\text { F } \\
\text { test }\end{array}$} & \multirow[b]{2}{*}{$\begin{array}{c}\mathbf{P} \\
\text { value(a) }\end{array}$} \\
\hline & & $\stackrel{0}{\dot{z}}$ & $\underset{n}{n}$ & 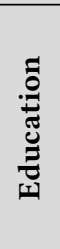 & 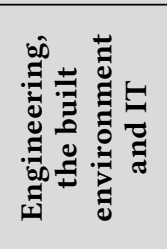 & 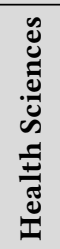 & 茎 & $\frac{\ddot{d}}{\stackrel{\Xi}{0}}$ & 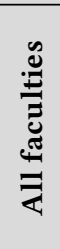 & & \\
\hline $\begin{array}{l}\text { Environmental } \\
\text { topic } 1\left(\mathrm{H}_{0,1.4}\right)\end{array}$ & $\begin{array}{l}\text { environmental } \\
\text { law }\end{array}$ & 4.0 & 3.8 & 3.8 & 3.6 & 3.7 & 4.9 & 4.2 & 3.9 & 3.151 & $0.005^{*}$ \\
\hline $\begin{array}{l}\text { Environmental } \\
\text { topic } 2\left(\mathrm{H}_{0,1.4}\right)\end{array}$ & $\begin{array}{l}\text { green design and } \\
\text { construction }\end{array}$ & 3.9 & 3.7 & 3.7 & 4.0 & 3.8 & 4.5 & 4.4 & 3.9 & 3.156 & $0.005^{*}$ \\
\hline $\begin{array}{l}\text { Environmental } \\
\text { topic } 3\left(\mathrm{H}_{0,1.4}\right)\end{array}$ & green IT & 3.8 & 3.7 & 4.0 & 3.9 & 3.8 & 4.3 & 4.1 & 3.9 & 1.135 & 0.341 \\
\hline $\begin{array}{l}\text { Environmental } \\
\text { topic } 4\left(\mathrm{H}_{0,1.4}\right)\end{array}$ & $\begin{array}{l}\text { environmental } \\
\text { economics }\end{array}$ & 3.6 & 3.6 & 3.5 & 3.4 & 3.4 & 3.6 & 4.1 & 3.7 & 2.819 & $0.011^{*}$ \\
\hline $\begin{array}{l}\text { Environmental } \\
\text { topic } 5\left(\mathrm{H}_{0,1.4}\right)\end{array}$ & ecological ethics & 3.7 & 3.6 & 3.8 & 3.7 & 3.6 & 4.1 & 4.1 & 3.8 & 1.839 & 0.091 \\
\hline $\begin{array}{l}\text { Environmental } \\
\text { topic } 6\left(\mathrm{H}_{0,1.4}\right)\end{array}$ & $\begin{array}{l}\text { environmental } \\
\text { journalism }\end{array}$ & 3.6 & 3.5 & 3.5 & 3.5 & 3.7 & 4.3 & 4.1 & 3.7 & 2.407 & $0.027^{*}$ \\
\hline $\begin{array}{l}\text { Environmental } \\
\text { topic } 7\left(\mathrm{H}_{0,1.4}\right)\end{array}$ & $\begin{array}{l}\text { environmental } \\
\text { reporting } \\
\text { (accounting) }\end{array}$ & 3.4 & 3.4 & 3.3 & 3.4 & 3.5 & 3.7 & 4.0 & 3.5 & 2.179 & $0.045^{*}$ \\
\hline
\end{tabular}

(a) An * indicates statistical significance at the $95 \%$ confidence level

(1999) found that desire to learn significantly influences environmental education and training and, consequently, environmental citizenship.

Based on the responses of the entire sample, the integration of topics relating to environmental law, green design, and construction, and green IT were regarded the most valuable (mean scores of 3.9 for each statement). Significant differences existed between students enrolled in different faculties regarding the five topics (three of which involved BES students, and will be discussed here). To identify significant pair-wise differences, the Tukey honest significant difference (HSD) post hoc test was performed.

With regard to the perceived value of green design and construction, the post hoc test revealed a significant difference between the perceptions of students registered in the Science faculty and BES students (post hoc $\mathrm{p}=0.002$ ). Of the two groups, science students attached the most value to incorporating this topic into existing modules.
In terms of the perceived value of environmental economics, significant differences existed in the perceptions of students registered in the Science and BES faculties (post hoc $\mathrm{p}=0.047$ ), between Science students and those registered in the Engineering, Built Environment and IT faculty (post hoc $\mathrm{p}=0.012$ ), as well as between Science and Health Sciences students (post hoc $\mathrm{p}=0.045$ ). In all three cases, Science students were the most in favour of incorporating environmental economics topics into existing modules (mean scores are indicated in Table 6).

With regard to the perceived value of environmental journalism, the post hoc test again showed a significant difference in the perceptions of students registered in the Science and BES faculties. Science students viewed integrating environmental journalism topics into an existing module as more valuable than students in the BES faculty did (post hoc $\mathrm{p}=0.030$ ).

It is encouraging to note that Science students were interested in topics outside of their 
immediate field of study. However, it is disconcerting that BES students consistently expressed lower interest in environmental education than students registered in other faculties did. Based on the findings shown in Table $6, \mathrm{H}_{0,1.4}$ can be rejected.

\section{Pro-environmental behaviours}

In this section of the questionnaire, students were requested to indicate to what extent they differences were identified in terms of the proenvironmental behaviours of students registered in different faculties. In terms of closing doors between air-conditioned and non-conditioned spaces, the post hoc test revealed significant pairwise differences among students from the Arts faculty and those from the Education and Science faculties (post hoc $\mathrm{p}=0.0353$ and $\mathrm{p}=0.040$ respectively). In both cases, Arts students were

TABLE 7: Pro-ENVIRONMENTAL BEHAVIOURS EXHIBITED PER FACULTY - STUDENTS

\begin{tabular}{|c|c|c|c|c|c|c|c|c|c|c|c|}
\hline \multirow[b]{2}{*}{ Code } & \multirow[b]{2}{*}{$\begin{array}{l}\text { While on campus, } \\
\text { do you: }\end{array}$} & \multicolumn{8}{|c|}{ Faculty - mean scores } & \multirow[b]{2}{*}{$\begin{array}{c}F \\
\text { test }\end{array}$} & \multirow[b]{2}{*}{$\begin{array}{c}\mathbf{P} \\
\text { value }^{(\mathrm{a})}\end{array}$} \\
\hline & & $\stackrel{n}{\dot{z}}$ & $\mathscr{n}$ & 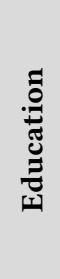 & 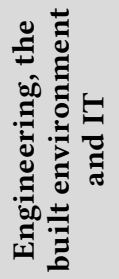 & 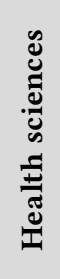 & 苂 & $\underset{\mathscr{e}}{\mathscr{E}}$ & 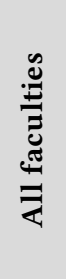 & & \\
\hline $\begin{array}{l}\text { Pro-environmental } \\
\text { behaviour } 1\left(\mathrm{H}_{0,1.5}\right)\end{array}$ & $\begin{array}{l}\text { print and copy } \\
\text { documents on both } \\
\text { sides of a page? }\end{array}$ & 3.5 & 3.6 & 2.5 & 3.6 & 3.2 & 3.2 & 3.5 & 3.5 & 1.354 & 0.233 \\
\hline $\begin{array}{l}\text { Pro-environmental } \\
\text { behaviour } 2\left(\mathrm{H}_{0,1.5}\right)\end{array}$ & $\begin{array}{l}\text { switch off your } \\
\text { computer when you are } \\
\text { done using it? }\end{array}$ & 3.4 & 3.1 & 2.6 & 3.4 & 2.9 & 3.3 & 3.2 & 3.2 & 0.615 & 0.719 \\
\hline $\begin{array}{l}\text { Pro-environmental } \\
\text { behaviour } 3\left(\mathrm{H}_{0,1.5}\right)\end{array}$ & $\begin{array}{l}\text { optimise the use of } \\
\text { sunlight to reduce the } \\
\text { use of electricity? }\end{array}$ & 2.7 & 2.9 & 2.5 & 2.9 & 2.4 & 2.8 & 2.5 & 2.7 & 1.156 & 0.330 \\
\hline $\begin{array}{l}\text { Pro-environmental } \\
\text { behaviour } 4\left(\mathrm{H}_{0,1.5}\right)\end{array}$ & $\begin{array}{l}\text { turn off lights where } \\
\text { possible? }\end{array}$ & 2.7 & 2.7 & 2.2 & 2.5 & 2.4 & 2.8 & 1.9 & 2.4 & 2.658 & $0.016^{*}$ \\
\hline $\begin{array}{l}\text { Pro-environmental } \\
\text { behaviour } 5\left(\mathrm{H}_{0,1.5}\right)\end{array}$ & $\begin{array}{l}\text { dispose hazardous } \\
\text { waste properly? }\end{array}$ & 2.7 & 2.7 & 2.5 & 2.5 & 2.3 & 3.2 & 2.2 & 2.5 & 1.175 & 0.320 \\
\hline $\begin{array}{l}\text { Pro-environmental } \\
\text { behaviour } 6\left(\mathrm{H}_{0,1.5}\right)\end{array}$ & $\begin{array}{l}\text { keep doors closed } \\
\text { between air } \\
\text { conditioned and non- } \\
\text { conditioned spaces? }\end{array}$ & 2.5 & 2.2 & 1.3 & 1.8 & 2.3 & 2.3 & 1.8 & 2.1 & 3.240 & $0.004^{*}$ \\
\hline $\begin{array}{l}\text { Pro-environmental } \\
\text { behaviour } 7\left(\mathrm{H}_{0,1.5}\right)\end{array}$ & $\begin{array}{l}\text { open taps only } \\
\text { minimally when using } \\
\text { them? }\end{array}$ & 1.6 & 1.7 & 1.2 & 1.8 & 1.8 & 1.7 & 1.8 & 1.7 & 1.001 & 0.425 \\
\hline $\begin{array}{l}\text { Pro-environmental } \\
\text { behaviour } 8\left(\mathrm{H}_{0,1.5}\right)\end{array}$ & $\begin{array}{l}\text { make sure you properly } \\
\text { close taps after using } \\
\text { them? }\end{array}$ & 1.1 & 1.3 & 1.2 & 1.4 & 1.5 & 1.1 & 1.3 & 1.3 & 1.211 & 0.301 \\
\hline
\end{tabular}

(a) An * indicates statistical significance at the $95 \%$ confidence level

engage in various pro-environmental behaviours. Descriptive and inferential statistics in this regard are provided in Table 7 .

As can be seen in Table 7, in contrast to the results previously discussed, BES students consistently had higher mean scores than students in some of the other faculties. In line with the overall sample, BES students often engaged in activities to conserve paper and electricity. Two significant more likely to engage in this simple, but effective, practice to conserve energy.

In respect of switching off unnecessary lights, significant differences were identified among students registered in the Science faculty and those registered in the Arts and BES faculties (post hoc $\mathrm{p}=0.037$ and 0.008 respectively). In both cases, Science students were less likely to switch off lights where possible. Based on the findings of Table $7, \mathrm{H}_{0,1.5}$ can be rejected. 
TABLE 8: INCENTIVES FOR ENGAGING IN PRO-ENVIRONMENTAL BEHAVIOURS - STUDENTS

\begin{tabular}{|c|c|c|c|c|c|c|c|c|c|c|}
\hline \multirow{2}{*}{ Code } & \multirow{2}{*}{ Statement } & \multicolumn{2}{|c|}{ Means } & \multicolumn{2}{|c|}{$\begin{array}{l}\text { Standard } \\
\text { deviation }\end{array}$} & \multicolumn{2}{|c|}{ Valid N } & \multirow{2}{*}{ df } & \multirow{2}{*}{$\begin{array}{c}\mathbf{t} \\
\text { value }\end{array}$} & \multirow{2}{*}{$\begin{array}{c}P \\
\text { value }\end{array}$} \\
\hline & & $\begin{array}{c}\text { Other } \\
\text { faculties }\end{array}$ & BES & $\begin{array}{c}\text { Other } \\
\text { faculties }\end{array}$ & BES & $\begin{array}{c}\text { Other } \\
\text { faculties }\end{array}$ & BES & & & \\
\hline $\begin{array}{l}\text { Incentive } 1 \\
\left(\mathrm{H}_{0,1.6}\right)\end{array}$ & $\begin{array}{l}\text { I would be more willing to engage } \\
\text { in greening actions at the university } \\
\text { if incentives were offered. }\end{array}$ & 3.8 & 3.9 & 1.16 & 1.16 & 226 & 98 & 322 & -0.199 & .842 \\
\hline $\begin{array}{l}\text { Incentive } 2 \\
\left(\mathrm{H}_{0,1.6}\right)\end{array}$ & $\begin{array}{l}\text { Incentives like competitions } \\
\text { between residences or faculties } \\
\text { for green status would encourage } \\
\text { me to become greener in my daily } \\
\text { activities. }\end{array}$ & 3.9 & 3.8 & 1.15 & 1.19 & 225 & 96 & 319 & 0.970 & .333 \\
\hline $\begin{array}{l}\text { Incentive } 3 \\
\left(\mathrm{H}_{0,1.6}\right)\end{array}$ & $\begin{array}{l}\text { A green award for any initiative to } \\
\text { protect the natural environment on } \\
\text { campus will motivate me to become } \\
\text { greener in my daily activities. }\end{array}$ & 3.7 & 3.6 & 1.10 & 1.27 & 224 & 98 & 320 & 1.158 & .248 \\
\hline $\begin{array}{l}\text { Incentive } 4 \\
\left(\mathrm{H}_{0,1.6}\right)\end{array}$ & $\begin{array}{l}\text { A Green Student of the Year award } \\
\text { will serve as incentive for me to } \\
\text { become more environmentally } \\
\text { sensitive. }\end{array}$ & 3.6 & 3.5 & 1.25 & 1.36 & 226 & 98 & 322 & 0.079 & .937 \\
\hline $\begin{array}{l}\text { Incentive } 5 \\
\left(\mathrm{H}_{0,1.6}\right)\end{array}$ & $\begin{array}{l}\text { A Green Researcher of the Year } \\
\text { award will serve as incentive for me } \\
\text { to become more environmentally } \\
\text { sensitive. }\end{array}$ & 3.6 & 3.4 & 1.19 & 1.21 & 226 & 98 & 322 & 1.553 & .121 \\
\hline
\end{tabular}

Incentives for engaging in proenvironmental behaviours

In this section, the perceptions of students were gauged regarding incentives that would motivate them to become more environmentally responsible in their daily activities. Table 8 provides the descriptive and inferential statistics in this regard.

With the exception of one statement, the mean scores for BES students were consistently lower than those of other students. Although not statistically significant, BES students did indicate that they would be more motivated to engage in pro-environmental behaviours if incentives were offered. This finding lends some support to the argument regarding the reductive utility maximisation theories to which these students are typically exposed. However, BES students were also less interested in other forms of recognition, such as green awards and competitions between residences for green status (although these findings were not statistically significant). As none of the p-values (contained in Table 8) indicated statistical significance, $\mathrm{H}_{0,1.6}$ cannot be rejected.

\section{EMPRICIAL FINDINGS - ACADEMICS}

\section{Environmental awareness and values}

Table 9 contains statistics on the level of environmental awareness among academics, as well as the importance they attach to selected environmental values.

In terms of the environmental awareness of academics, BES and other academics were neutral regarding an increase in the awareness of their environmental impact. A significant difference was identified with respect to enhanced environmental awareness; however, this did not relate to the BES faculty. Furthermore, both BES and other academics agreed that they have an impact on the natural environment; however BES academics were slightly less convinced than their counterparts of their impact on the environment.

As shown in Table 8, two statements dealing with environmental values showed statistically significant differences between academics in the BES faculty and those in other faculties. In both cases, BES academics viewed the maintenance of non-human nature as significantly less important than their counterparts in other faculties did (post hoc $\mathrm{p}=0.038$ and $\mathrm{p}=0.043$ respectively). 
TABle 9: EnVironmental aWAREness AND VAlues - ACADEMics

\begin{tabular}{|c|c|c|c|c|c|c|c|c|c|}
\hline \multirow[b]{2}{*}{ Code } & \multirow[b]{2}{*}{ Statement } & \multicolumn{2}{|c|}{ Mean scores } & \multicolumn{2}{|c|}{ Valid N } & \multicolumn{2}{|c|}{ Standard deviation } & \multirow{2}{*}{$\begin{array}{c}F \\
\text { test }\end{array}$} & \multirow{2}{*}{$\begin{array}{c}\mathbf{P} \\
\text { value }^{(\mathrm{a})}\end{array}$} \\
\hline & & $\begin{array}{c}\text { Other } \\
\text { faculties }\end{array}$ & BES & $\begin{array}{c}\text { Other } \\
\text { faculties }\end{array}$ & BES & $\begin{array}{c}\text { Other } \\
\text { faculties }\end{array}$ & BES & & \\
\hline $\begin{array}{l}\text { Environmental } \\
\text { values } 2\left(\mathrm{H}_{0,2.2}\right)\end{array}$ & $\begin{array}{l}\text { The protection of the } \\
\text { natural environment on } \\
\text { the campus where I work } \\
\text { is important to me. }\end{array}$ & 4.7 & 4.5 & 117 & 31 & 0.9 & 0.6 & 1.850 & .159 \\
\hline $\begin{array}{l}\text { Environmental } \\
\text { values } 1\left(\mathrm{H}_{0,2.2}\right)\end{array}$ & $\begin{array}{l}\text { I respect all plant life on } \\
\text { the campus where I work. }\end{array}$ & 4.7 & 4.5 & 117 & 31 & 0.8 & 0.6 & 1.181 & .308 \\
\hline $\begin{array}{l}\text { Environmental } \\
\text { values } 3\left(\mathrm{H}_{0,2.2}\right)\end{array}$ & $\begin{array}{l}\text { I respect all animal life on } \\
\text { the campus where I work. }\end{array}$ & 4.6 & 4.5 & 117 & 31 & 0.9 & 0.7 & 1.181 & .308 \\
\hline $\begin{array}{l}\text { Environmental } \\
\text { values } 4\left(\mathrm{H}_{0,2.2}\right)\end{array}$ & $\begin{array}{l}\text { It is important to me } \\
\text { that plant biodiversity be } \\
\text { maintained on the campus } \\
\text { where I work. }\end{array}$ & 4.6 & 4.1 & 117 & 31 & 0.9 & 0.7 & 5.529 & $.004^{*}$ \\
\hline $\begin{array}{l}\text { Environmental } \\
\text { values } 5\left(\mathrm{H}_{0,2.2}\right)\end{array}$ & $\begin{array}{l}\text { It is important to me that } \\
\text { animal biodiversity be } \\
\text { maintained on the campus } \\
\text { where I work. }\end{array}$ & 4.5 & 4.0 & 117 & 31 & 0.9 & 0.7 & 5.009 & $.007^{*}$ \\
\hline $\begin{array}{l}\text { Awareness of } \\
\text { environmental } \\
\text { impact } 1\left(\mathrm{H}_{0,2.1}\right)\end{array}$ & $\begin{array}{l}\text { I have an impact on the } \\
\text { natural environment of } \\
\text { the campus where I work. }\end{array}$ & 4.1 & 3.9 & 117 & 31 & 1.2 & 1.1 & 0.475 & .622 \\
\hline $\begin{array}{l}\text { Awareness of } \\
\text { environmental } \\
\text { impact } 2\left(\mathrm{H}_{0,2.1}\right)\end{array}$ & $\begin{array}{l}\text { I have become more aware } \\
\text { of my impact on the } \\
\text { natural environment of } \\
\text { the campus where I work } \\
\text { within the past } 12 \text { months. }\end{array}$ & 3.1 & 3.2 & 117 & 31 & 1.4 & 1.3 & 4.078 & $.018^{*}$ \\
\hline
\end{tabular}

(a) An * indicates statistical significance at the $95 \%$ confidence level

TABLE 10: IMPLications of ENVIRONMENTAL MANAGEMENT - ACADEMICS

\begin{tabular}{|c|c|c|c|c|c|c|c|c|c|}
\hline \multirow[b]{2}{*}{ Code } & \multirow[b]{2}{*}{ Statement } & \multicolumn{2}{|c|}{ Mean scores } & \multicolumn{2}{|c|}{ Valid N } & \multicolumn{2}{|c|}{ Standard deviation } & \multirow{2}{*}{$\begin{array}{c}F \\
\text { test }\end{array}$} & \multirow{2}{*}{$\begin{array}{c}P \\
\text { value }\end{array}$} \\
\hline & & $\begin{array}{l}\text { Other } \\
\text { Faculties }\end{array}$ & BES & $\begin{array}{l}\text { Other } \\
\text { faculties }\end{array}$ & BES & $\begin{array}{l}\text { Other } \\
\text { faculties }\end{array}$ & BES & & \\
\hline $\begin{array}{l}\text { Environmental } \\
\text { implications } 2 \\
\left(\mathrm{H}_{0,2.3}\right)\end{array}$ & $\begin{array}{l}\text { It is important to me that } \\
\text { the university becomes } \\
\text { a pioneer in the field } \\
\text { of good environmental } \\
\text { management among South } \\
\text { African universities. }\end{array}$ & 4.4 & 4.3 & 116 & 31 & 0.9 & 0.8 & 0.407 & 0.665 \\
\hline $\begin{array}{l}\text { Environmental } \\
\text { implications } 1 \\
\left(\mathrm{H}_{0,2.3}\right)\end{array}$ & $\begin{array}{l}\text { It is important to me that } \\
\text { the university becomes } \\
\text { a pioneer in the field } \\
\text { of good environmental } \\
\text { management among } \\
\text { organisations in } \\
\text { South Africa. }\end{array}$ & 4.4 & 4.3 & 117 & 31 & 0.9 & 0.8 & 0.117 & 0.889 \\
\hline $\begin{array}{l}\text { Environmental } \\
\text { implications } 3 \\
\left(\mathrm{H}_{0,2.3}\right)\end{array}$ & $\begin{array}{l}\text { Green initiatives will save } \\
\text { the university money. }\end{array}$ & 3.8 & 4.0 & 116 & 30 & 1.2 & 1.1 & 0.41 & 0.659 \\
\hline $\begin{array}{l}\text { Environmental } \\
\text { implications } 4 \\
\left(\mathrm{H}_{0,2.3}\right)\end{array}$ & $\begin{array}{l}\text { Green initiatives will not be } \\
\text { too expensive. }\end{array}$ & 3.5 & 3.2 & 116 & 31 & 1.2 & 1.1 & 1.360 & 0.258 \\
\hline
\end{tabular}


It could thus be said that academics in the BES faculty probably have a moderate mechanistic view of nature (as characterised earlier), and may be perpetuating this view through their teaching activities.

The findings (shown in Table 9) indicated that $\mathrm{H}_{0,2.1}$ cannot be reject, whereas $\mathrm{H}_{0,2.2}$ can be rejected.

\section{Implications of environmental management}

More details on the perceptions of academics with regard to the financial implications of going green are provided in Table 10.

As illustrated in Table 10, BES academics had lower mean scores than academics in other faculties for almost all statements dealing with the implications of environmental management. Academics in other faculties perceived all of the statements as highly important, whereas BES academics only attached a high level of importance to three of the four statements. BES academics were neutral when asked if greening the university would be too expensive. However, academics working in the BES faculty were more convinced that environmental management would lead to cost savings for the university. Since no statistically significant differences were observed, $\mathrm{H}_{0,2.3}$ cannot be rejected.

\section{Environmental education}

Table 11 contains descriptive and inferential statistics relating to the perceptions of academics on integrating green topics into existing modules.

The mean scores for the entire academic sample indicated that academics placed high importance on the integration of all the selected green topics. This was also the case in students' perceptions of environmental education (see Table 7). Academics in the Law faculty consistently attached more value to integrating green topics into curricula than other faculties did. BES academics did not differ much in their opinions on environmental education. Academics were also asked if "all lecturers at NMMU should include environmental management topics in modules offered at undergraduate level." In terms of this question, BES academics were more convinced of the need for integrating environmental management topics in modules offered at undergraduate level

TABLe 11: Environmental EdUCATion - ACAdEmics

\begin{tabular}{|c|c|c|c|c|c|c|c|c|c|c|c|}
\hline \multirow[b]{2}{*}{ Codes } & \multirow[b]{2}{*}{$\begin{array}{l}\text { It will be valuable if a } \\
\text { topic such as } \\
\text { be incorporated into } \\
\text { an EXISTING module. }\end{array}$} & \multicolumn{8}{|c|}{ Faculty - mean scores } & \multirow[b]{2}{*}{$\begin{array}{c}F \\
\text { test }\end{array}$} & \multirow[b]{2}{*}{$\begin{array}{c}\mathbf{P} \\
\text { value }\end{array}$} \\
\hline & & $\stackrel{n}{\dot{L}}$ & 空 & 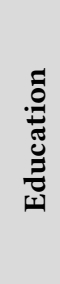 & 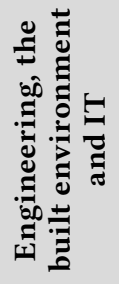 & 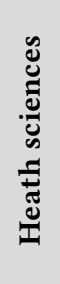 & 疍 & 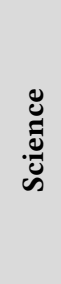 & 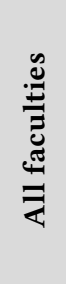 & & \\
\hline $\begin{array}{l}\text { Environmental } \\
\text { topic } 7\left(\mathrm{H}_{0,2.4}\right)\end{array}$ & $\begin{array}{l}\text { environmental reporting } \\
\text { (accounting) }\end{array}$ & 3.9 & 4.1 & 3.6 & 3.6 & 3.4 & 5.0 & 3.8 & 3.8 & 1.295 & 0.266 \\
\hline $\begin{array}{l}\text { Environmental } \\
\text { topic } \mathbf{5}\left(\mathrm{H}_{0,2.4}\right)\end{array}$ & ecological ethics & 4.2 & 4.1 & 4.0 & 3.8 & 4.1 & 5.0 & 4.0 & 4.1 & 0.537 & 0.779 \\
\hline $\begin{array}{l}\text { Environmental } \\
\text { topic } 2\left(\mathrm{H}_{0,2.4}\right)\end{array}$ & $\begin{array}{l}\text { green design and } \\
\text { construction }\end{array}$ & 4.2 & 4.1 & 4.1 & 4.4 & 4.1 & 4.5 & 4.2 & 4.2 & 0.148 & 0.989 \\
\hline $\begin{array}{l}\text { Environmental } \\
\text { topic } 4\left(\mathrm{H}_{0,2.4}\right)\end{array}$ & $\begin{array}{l}\text { environmental } \\
\text { economics }\end{array}$ & 3.9 & 4.0 & 4.0 & 3.9 & 3.7 & 5.0 & 4.0 & 4.0 & 0.623 & 0.711 \\
\hline $\begin{array}{l}\text { Environmental } \\
\text { topic } 3\left(\mathrm{H}_{0,2.4}\right)\end{array}$ & green IT & 4.0 & 4.0 & 4.3 & 3.9 & 4.1 & 5.0 & 4.1 & 4.1 & 0.466 & 0.832 \\
\hline $\begin{array}{l}\text { Environmental } \\
\text { topic } \mathbf{1}\left(\mathrm{H}_{0,2.4}\right)\end{array}$ & environmental law & 4.0 & 3.9 & 4.1 & 3.5 & 4.0 & 5.0 & 4.1 & 4.0 & 0.734 & 0.623 \\
\hline $\begin{array}{l}\text { Environmental } \\
\text { topic } 6\left(\mathrm{H}_{0,2.4}\right)\end{array}$ & $\begin{array}{l}\text { environmental } \\
\text { journalism }\end{array}$ & 3.8 & 3.6 & 3.5 & 3.6 & 3.8 & 5.0 & 3.7 & 3.7 & 0.665 & 0.678 \\
\hline
\end{tabular}


TABle 12: Pro-environmental behaviours - academics

\begin{tabular}{|c|c|c|c|c|c|c|c|c|c|c|c|}
\hline \multirow[b]{2}{*}{ Code } & \multirow[b]{2}{*}{$\begin{array}{l}\text { While on campus, } \\
\text { do you: }\end{array}$} & \multicolumn{8}{|c|}{ Faculty - mean scores } & \multirow[b]{2}{*}{$\begin{array}{c}\mathrm{F} \\
\text { test }\end{array}$} & \multirow[b]{2}{*}{$\begin{array}{c}\mathbf{P} \\
\text { value }^{(\mathrm{a})}\end{array}$} \\
\hline & & $\stackrel{2}{\dot{z}}$ & 站 & 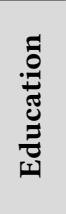 & 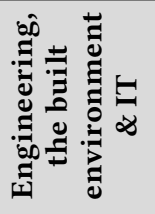 & 氖造 & 胥 & $\stackrel{\Xi}{\tilde{e}}$ & 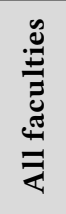 & & \\
\hline $\begin{array}{l}\text { Pro-environmental } \\
\text { behaviour } 5\left(\mathrm{H}_{0,2.5}\right)\end{array}$ & $\begin{array}{l}\text { dispose hazardous } \\
\text { waste properly? }\end{array}$ & 2.1 & 2.8 & 2.7 & 2.6 & 1.9 & 3.0 & 2.0 & 2.3 & 1.702 & 0.126 \\
\hline $\begin{array}{l}\text { Pro-environmental } \\
\text { behaviour } 3\left(\mathrm{H}_{0,2.5}\right)\end{array}$ & $\begin{array}{l}\text { optimise the use of } \\
\text { sunlight to reduce the } \\
\text { use of electricity? }\end{array}$ & 2.1 & 2.6 & 1.6 & 3.1 & 1.8 & 2.5 & 1.8 & 2.2 & 3.676 & $0.002^{*}$ \\
\hline $\begin{array}{l}\text { Pro-environmental } \\
\text { behaviour } 1\left(\mathrm{H}_{0,2.5}\right)\end{array}$ & $\begin{array}{l}\text { print and copy } \\
\text { documents on both } \\
\text { sides of a page? }\end{array}$ & 2.5 & 2.6 & 2.5 & 2.8 & 2.1 & 2.5 & 2.8 & 2.6 & 0.844 & 0.538 \\
\hline $\begin{array}{l}\text { Pro-environmental } \\
\text { behaviour } 6\left(\mathrm{H}_{0,2.5}\right)\end{array}$ & $\begin{array}{l}\text { keep doors closed } \\
\text { between air- } \\
\text { conditioned and non- } \\
\text { conditioned spaces? }\end{array}$ & 1.8 & 2.4 & 1.7 & 2.1 & 1.7 & 2.5 & 1.8 & 1.9 & 1.440 & 0.204 \\
\hline $\begin{array}{l}\text { Pro-environmental } \\
\text { behaviour } 2\left(\mathrm{H}_{0,2.5}\right)\end{array}$ & $\begin{array}{l}\text { switch off your } \\
\text { computer when you are } \\
\text { done using it? }\end{array}$ & 1.7 & 2.0 & 1.8 & 2.9 & 2.2 & 3.5 & 2.5 & 2.2 & 2.185 & $0.048^{*}$ \\
\hline $\begin{array}{l}\text { Pro-environmental } \\
\text { behaviour } 4\left(\mathrm{H}_{0,2.5}\right)\end{array}$ & $\begin{array}{l}\text { turn off lights where } \\
\text { possible? }\end{array}$ & 1.6 & 1.9 & 1.5 & 2.2 & 1.5 & 2.0 & 1.6 & 1.7 & 1.176 & 0.323 \\
\hline $\begin{array}{l}\text { Pro-environmental } \\
\text { behaviour } 7\left(\mathrm{H}_{0,2.5}\right)\end{array}$ & $\begin{array}{l}\text { open taps only } \\
\text { minimally when using } \\
\text { them? }\end{array}$ & 1.4 & 1.7 & 1.3 & 2.4 & 1.5 & 1.0 & 1.5 & 1.6 & 2.778 & $0.014^{*}$ \\
\hline $\begin{array}{l}\text { Pro-environmental } \\
\text { behaviour } 8\left(\mathrm{H}_{0,2.5}\right)\end{array}$ & $\begin{array}{l}\text { make sure you properly } \\
\text { close taps after using } \\
\text { them? }\end{array}$ & 1.2 & 1.1 & 1.1 & 1.6 & 1.1 & 3.0 & 1.2 & 1.2 & 3.353 & $0.004^{*}$ \\
\hline
\end{tabular}

(a) An * indicates statistical significance at the $95 \%$ confidence level

than their colleagues in the Science faculty (post hoc $\mathrm{p}=0.035)$.

In an open-ended question, several academics indicated that they were willing to integrate more green topics into modules, but required information and training before doing so. Many of these respondents were in the BES faculty. As a significant difference existed in the perceptions of academics on this issue, $\mathrm{H}_{0,2.4}$ can be rejected.

\section{Pro-environmental behaviours}

As in the case of students, academics were asked to indicate to what extent they engaged in certain pro-environmental behaviours. The descriptive and inferential statistics in this regard are provided in Table 12.

According to the statistics contained in Table 12 , all academics attached a relatively low level of importance to almost all the statements dealing with pro-environmental behaviours. Responses of BES academics followed the same trend. BES academics were neutral regarding the importance of properly disposing of hazardous waste, optimising the use of sunlight to reduce electricity usage, and printing documents on both sides of a page. These academics placed relatively low importance on all other statements relating to pro-environmental behaviours.

Four significant differences were identified between academics working in different faculties, all related to energy and water usage on campus. The post hoc test revealed that only one of these significant differences involved BES academics (post hoc $\mathrm{p}=0.003$ ). In terms of water usage, academics working in the Law faculty viewed closing taps properly after using them as significantly more important than BES academics did. Given this finding, $\mathrm{H}_{0,2.5}$ can be rejected. 
TABLE 13: INCENTIVES FOR ENGAGING IN PRO-ENVIRONMENTAL BEHAVIOURS - ACADEMICS

\begin{tabular}{|c|c|c|c|c|c|c|c|c|c|}
\hline \multirow{2}{*}{ Code } & \multirow{2}{*}{ Statement } & \multicolumn{2}{|c|}{ Mean scores } & \multicolumn{2}{|c|}{ Valid N } & \multicolumn{2}{|c|}{$\begin{array}{l}\text { Standard } \\
\text { deviation }\end{array}$} & \multirow{2}{*}{$\begin{array}{c}\text { F } \\
\text { test }\end{array}$} & \multirow{2}{*}{$\begin{array}{c}\mathbf{P} \\
\text { value }^{(\mathrm{a})}\end{array}$} \\
\hline & & $\begin{array}{c}\text { Other } \\
\text { faculties }\end{array}$ & BES & $\begin{array}{c}\text { Other } \\
\text { faculties }\end{array}$ & BES & $\begin{array}{c}\text { Other } \\
\text { faculties }\end{array}$ & BES & & \\
\hline $\begin{array}{l}\text { Incentive } \\
\mathbf{1}\left(\mathrm{H}_{0,2.4}\right)\end{array}$ & $\begin{array}{l}\text { I would be more willing to } \\
\text { engage in greening actions at } \\
\text { the university if incentives were } \\
\text { offered. }\end{array}$ & 3.3 & 3.7 & 101 & 31 & 1.5 & 1.2 & 1.136 & 0.34 \\
\hline $\begin{array}{l}\text { Incentive } \\
\mathbf{2}\left(\mathrm{H}_{0,2.4}\right)\end{array}$ & $\begin{array}{l}\text { A Green Lecturer of the Year } \\
\text { award will serve as incentive } \\
\text { for me to become more } \\
\text { environmentally sensitive. }\end{array}$ & 2.9 & 3.5 & 100 & 31 & 1.4 & 1.5 & 5.049 & $0.001^{*}$ \\
\hline $\begin{array}{l}\text { Incentive } \\
\mathbf{3}\left(\mathrm{H}_{0,2.4}\right)\end{array}$ & $\begin{array}{l}\text { A Green Employee of the Year } \\
\text { award will serve as incentive } \\
\text { for me to become more } \\
\text { environmentally sensitive. }\end{array}$ & 2.8 & 3.5 & 101 & 31 & 1.4 & 1.3 & 2.282 & 0.061 \\
\hline $\begin{array}{l}\text { Incentive } \\
\mathbf{4}\left(\mathrm{H}_{0,2.4}\right)\end{array}$ & $\begin{array}{l}\text { A Green researcher of the Year } \\
\text { award will serve as incentive } \\
\text { for me to become more } \\
\text { environmentally sensitive. }\end{array}$ & 2.9 & 3.4 & 101 & 31 & 1.4 & 1.4 & 2.012 & 0.094 \\
\hline $\begin{array}{l}\text { Incentive } \\
\mathbf{5}\left(\mathrm{H}_{0,2.4}\right)\end{array}$ & $\begin{array}{l}\text { A Green Award for any } \\
\text { initiative to protect the natural } \\
\text { environment on campus will } \\
\text { motivate me to become greener } \\
\text { in my daily activities. }\end{array}$ & 3.1 & 3.4 & 100 & 31 & 1.4 & 1.3 & 3.688 & $0.006^{*}$ \\
\hline $\begin{array}{l}\text { Incentive } \\
\mathbf{6}\left(\mathrm{H}_{0,2.4}\right)\end{array}$ & $\begin{array}{l}\text { Incentives like competitions } \\
\text { between departments or } \\
\text { faculties for green status would } \\
\text { encourage me to become } \\
\text { greener in my daily activities. }\end{array}$ & 3.1 & 3.4 & 101 & 31 & 1.4 & 1.3 & 1.153 & 0.332 \\
\hline
\end{tabular}

(a) An ${ }^{*}$ indicates statistical significance at the $95 \%$ confidence level

\section{Incentives for going green}

Table 13 contains the incentives that could motivate academics to become more environmentally responsible citizens.

The mean scores of academics in the BES faculty were consistently higher (for all the incentives), compared to those of academics in other faculties. Irrespective of faculty, academics placed the highest value on incentives in motivating them to be more environmentally friendly; however, BES academics attached a slightly higher importance to this statement. Two statistically significant differences were noted. In the first instance, the post hoc test was not powerful enough to indicate pair-wise differences at the $5 \%$ confidence level. Secondly, academics in the BES faculty indicated that they would be more motivated to go green if awards for these initiatives were offered. As such, $\mathrm{H}_{0,2.6}$ can be rejected.

As in the case of students, academics expressed a willingness to engage in pro-environmental behaviours at the university, if incentives were offered. However, based on the mean score for this question, students were more interested in going green than academics were, should incentives be offered (students' mean score = 3.9 ; academics' mean score $=3.4$ ). Green awards and competitions for green status between departments and faculties were highly regarded by academics as incentives for going green.

In an open-ended question, academics were asked to provide examples of other incentives that would motivate them to become greener whilst on campus. As in the case of students, the mostmentioned incentives for going green (suggested by $55 \%$ of participating academics)involved money, prizes, and competitions. It should, however, be noted that quite a number of academics (21.7\%) stated that they did not need incentives to become more environmentally friendly in their daily activities. As this was not the case with students, it would appear that intrinsically motivated academics could be valuable role models in 
the efforts of higher education institutions to change moral orientations. They could show students and colleagues that a concern for the natural environment should stem from a sense of moral obligation, and not depend on a reward being offered. One academic remarked: "For me, going green is a rational decision, not based on incentives. Use information, not incentives."

\section{SUMMARY AND CONCLUSIONS}

This article argues that there is a need for greater recognition of the interwovenness of humans and the natural environment. More specifically, the role of business education in creating an environmentally responsible citizenry is questioned. Based on the premise that business education erodes the character of students and could thus impede the cultivation of environmental citizenship, this article set out to assess whether differences exist between the perceptions of BES students and academics and their counterparts in other faculties in terms of their environmental awareness and values, the implications of environmental management, their desire to learn about environmental topics, the extent to which they engage in proenvironmental behaviours, and the incentives that could motivate them to engage in proenvironmental behaviours.

A summary of the statistical outcomes of this research is provided in Table 14 .

The empirical results showed that there are, in fact, differences between BES students and students of other faculties in terms of the environmental values they exhibit, their perceptions of the implications of environmental management, their desire to learn about environmental topics, and the extent to which they engage in pro-environmental behaviours. BES students exhibited less respect for, and were less concerned about, protecting and preserving non-human nature. Furthermore, BES students were also less convinced that environmental management could lead to cost savings for the university. In terms of their desire to learn about environmental topics, BES students attached significantly less importance to incorporating green design and construction, environmental economics, and environmental journalism into existing modules, compared to Science students.

Significant differences were observed between BES and other academics in terms of the environmental values they exhibit, their desire to incorporate environmental topics in the module they teach, the extent to which they engage in pro-environmental behaviours, and the incentives that could motivate them to engage in pro-environmental behaviours. BES academics attached significantly less importance to preserving non-human nature than academics from other faculties did. However, BES academics were more convinced of the value of integrating environmental management topics into modules offered at undergraduate level. In terms of the extent to which academics engaged in proenvironmental behaviours, BES academics indicated that they would be significantly more motivated to engage in pro-environmental behaviours if any kind of incentive were offered.

This research also produced some unintended outcomes, which were not accounted for in the initial research process. Some of these are: students and academics are motivated by money, prizes, and competitions to go green, BES students place the least importance on environmental topics being incorporated into modules, and Science students and academics seem to prescribe to environmental citizenship to a larger extent than other students and academics do (at least for some of the issues investigated in this study). It is disconcerting that BES students expressed almost no interest in these topics. This might be explained by the fact that South Africa is an emerging economy, and topics addressed in business modules are more likely to centre on issues such as job creation, entrepreneurship, and poverty alleviation, rather than environmental management topics. However, these students need to be taught that what is good for the natural environment can also be good for the bottom line of a business.

Given the differences between BES students and academics and their peers in other faculties, it 
TABLE 14: SUMMARY OF EMPIRICAL FINDINGS

\begin{tabular}{|c|c|c|c|}
\hline Hypothesis & & Summary of significant differences & $\begin{array}{l}\text { Outcome of } \\
\text { hypothesis test }\end{array}$ \\
\hline \multirow{6}{*}{$\begin{array}{l}\text { There is no } \\
\text { difference } \\
\text { between BES } \\
\text { students and } \\
\text { students in } \\
\text { other faculties } \\
\text { in terms of: }\end{array}$} & $\begin{array}{l}\mathrm{H}_{0,1,1}: \text { their awareness of } \\
\text { their impact on the natural } \\
\text { environment }\end{array}$ & & $\begin{array}{l}\text { Cannot reject the null } \\
\text { hypothesis }\end{array}$ \\
\hline & $\begin{array}{l}\mathrm{H}_{0,1,2:}: \text { the environmental values } \\
\text { they exhibit }\end{array}$ & $\begin{array}{l}\text { BES students exhibited significantly less } \\
\text { respect for plant and animal life, and were } \\
\text { also less concerned about protecting and } \\
\text { preserving plant and animal biodiversity } \\
\text { than students registered in other faculties. }\end{array}$ & $\begin{array}{l}\text { Can reject the null } \\
\text { hypothesis }\end{array}$ \\
\hline & $\begin{array}{l}\mathrm{H}_{0,1:} \text { : their perceptions on the } \\
\text { implications of environmental } \\
\text { management }\end{array}$ & $\begin{array}{l}\text { BES students were not as convinced as their } \\
\text { counterparts in other faculties that green } \\
\text { initiatives will save the university money. }\end{array}$ & $\begin{array}{l}\text { Can reject the null } \\
\text { hypothesis }\end{array}$ \\
\hline & $\begin{array}{l}\mathrm{H}_{0,1.4} \text { : their desire to learn about } \\
\text { environmental topics in their } \\
\text { modules }\end{array}$ & $\begin{array}{l}\text { BES students attached less value } \\
\text { to incorporating green design and } \\
\text { construction, environmental economics, } \\
\text { and environmental journalism into existing } \\
\text { modules than Science students. }\end{array}$ & $\begin{array}{l}\text { Can reject the null } \\
\text { hypothesis }\end{array}$ \\
\hline & $\begin{array}{l}\mathrm{H}_{0,1.5} \text { : the extent to which they } \\
\text { engage in pro-environmental } \\
\text { behaviours }\end{array}$ & $\begin{array}{l}\text { BES students were more likely, } \\
\text { compared to Science students, to } \\
\text { switch off lights (to save energy) where } \\
\text { possible. }\end{array}$ & $\begin{array}{l}\text { Can reject the null } \\
\text { hypothesis }\end{array}$ \\
\hline & $\begin{array}{l}\mathrm{H}_{0,1,6} \text { : the incentives that could } \\
\text { motivate them to engage in pro- } \\
\text { environmental behaviours }\end{array}$ & & $\begin{array}{l}\text { Cannot reject the null } \\
\text { hypothesis }\end{array}$ \\
\hline \multirow{6}{*}{$\begin{array}{l}\text { There is no } \\
\text { difference } \\
\text { between BES } \\
\text { academics and } \\
\text { academics in } \\
\text { other faculties } \\
\text { in terms of: }\end{array}$} & $\begin{array}{l}\mathrm{H}_{0,2}: \text { their awareness of } \\
\text { their impact on the natural } \\
\text { environment }\end{array}$ & & $\begin{array}{l}\text { Cannot reject the null } \\
\text { hypothesis }\end{array}$ \\
\hline & $\begin{array}{l}\mathrm{H}_{0,2.2}: \text { the environmental values } \\
\text { they exhibit }\end{array}$ & $\begin{array}{l}\text { BES academics viewed the maintenance } \\
\text { of non-human nature as significantly } \\
\text { less important than their counterparts } \\
\text { in other faculties did. }\end{array}$ & $\begin{array}{l}\text { Can reject the null } \\
\text { hypothesis }\end{array}$ \\
\hline & $\begin{array}{l}\mathrm{H}_{0,2:} \text { : their perceptions on the } \\
\text { implications of environmental } \\
\text { management }\end{array}$ & & $\begin{array}{l}\text { Cannot reject the null } \\
\text { hypothesis }\end{array}$ \\
\hline & $\begin{array}{l}\mathrm{H}_{0,2.2}: \text { their desire to incorporate } \\
\text { environmental topics in their } \\
\text { modules }\end{array}$ & $\begin{array}{l}\text { BES academics were more convinced of } \\
\text { the need for integrating environmental } \\
\text { management topics into modules } \\
\text { offered at undergraduate level. }\end{array}$ & $\begin{array}{l}\text { Can reject the null } \\
\text { hypothesis }\end{array}$ \\
\hline & $\begin{array}{l}\mathrm{H}_{0,2.5}: \text { the extent to which they } \\
\text { engage in pro-environmental } \\
\text { behaviours }\end{array}$ & $\begin{array}{l}\text { BES academics viewed the proper } \\
\text { closing of taps (to save a precious } \\
\text { natural resource) as significantly less } \\
\text { important, compared to academics in } \\
\text { the Law faculty. }\end{array}$ & $\begin{array}{l}\text { Can reject the null } \\
\text { hypothesis }\end{array}$ \\
\hline & $\begin{array}{l}\mathrm{H}_{0,2,6} \text { : the incentives that could } \\
\text { motivate them to go green }\end{array}$ & $\begin{array}{l}\text { Compared to other academics, the BES } \\
\text { academics indicated that they would be } \\
\text { more motivated to go green if incentives of } \\
\text { any kind were offered. }\end{array}$ & $\begin{array}{l}\text { Can reject the null } \\
\text { hypothesis }\end{array}$ \\
\hline
\end{tabular}

could be concluded that signs exist that suggest that current business education is not ideal for cultivating environmental citizenship. In the words of Curry (2007), business students and academics in this sample can be classified as being "light green" in their ecological orientation. The urgent need for environmentally responsible graduates in the South African and international labour market means that serious consideration should be given to addressing this situation.

\section{RECOMMENDATIONS}

It is recommended that business education be transformed and re-orientated to meet the changing ecological needs of both business and society. This could be done by including more environmental topics in business modules, and exposing students to more inclusive models of economic, social, and ecological interactions. However, the re-education of BES academics 
is needed to accomplish this task. This reeducation should be based on a multidisciplinary approach to learning about business and the interconnectedness of social and environmental systems, and enable academics to be role models for environmental citizenship.

Therefore, in dealing with the discrepancy in the environmental values exhibited by BES students and the importance that students and academics placed on money and prizes as incentives to go green, the researchers suggest that academics turn to the principles advocated by virtue ethicists. In the context of this study, academics are thus encouraged to prescribe to and instil virtues such as respect for the natural environment in their peers and students. The researchers are proposing that more should be done to cultivate environmental virtues/values and a sense of moral obligation among students and academics, particularly among those in the BES faculty. This is important for the long-term sustainability of healthy ecological relations, and would, at the same time, benefit business profitability and sustainability.

Taking into account the lack of interest amongst BES students to learn about environmental topics, it is recommended that BES faculties make a concerted effort to create awareness regarding the importance of such topics, which could prepare them to be competitive in a lowcarbon economy. New career opportunities that accompany a shift towards a low-carbon economy should also be brought to the attention of BES students - this could be accomplished through career days and counselling. BES academics should also collaborate with Science academics to identify the factors in Science education that could possibly result in a greater recognition of the interdependence of human and non-human nature.

\section{LIMITATIONS OF THE STUDY}

The outcomes of this research should be interpreted within a number of contextual constraints. Firstly, the outcomes apply to only one university in South Africa, and may thus not be universally applicable. Secondly, the outcomes are dominated by the perceptions of undergraduate students $(79.4 \%$ of all students; $86.9 \%$ of BES students), who may not yet have had the full benefit of management education at tertiary level. Thirdly, the data presented in this article are self-reported, and not actual observations. Thus, only the perceptions of respondents with regard to the issues investigated were analysed and interpreted, an approach that lends itself to social desirability bias on the part of respondents (Thompson \& Phua, 2005). Lastly, only a limited number of factors that have a bearing on environmental citizenship were investigated; many other factors such as the ability to learn, the ability to act, and even religious affiliation have been proven to have a strong influence on environmental citizenship (Hawthorne \& Alabaster, 1999).

\section{SUGGESTIONS FOR FUTURE RESEARCH}

Given the restriction on the generalisability of the outcomes of this research, imposed by the sample, it would be useful for future research to consider using a larger, more representative sample. Once the sampling issue has been addressed, it would also be interesting to investigate whether differences can be identified amongst students who have had greater exposure to business education and those who have not (e.g., postgraduate vs. undergraduate business students). Furthermore, given the increasing recognition of environmental issues, future research could also take a longitudinal approach to identifying differences over time in business students' orientation towards the environment.

To overcome the social desirability bias of respondents, researchers could make use of triangulation, by employing different research methods and using multiple data sources. By doing this, researchers could validate the self-reported data provided by respondents, and possibly obtain more accurate representations of reality. Future studies in environmental citizenship should also take a more encompassing approach to 
investigating this phenomenon. This would mean paying attention to a larger range of factors that have an impact on environmental citizenship.

Based on the differences identified between BES and other students and academics in this research, great value could be added to understanding these differences by investigating their possible causes. Is it possible that students with low environmental consciousness are drawn to business studies? Is the exposure to business education really the cause of discrepancies in environmental citizenship? If so, then the problem with business students' attitudes towards the natural environment may not be causally connected to the economic models to which they are exposed. Rather, it may mean that they need some form of remedial education to overcome the values and personal inclinations regarding the environment that they bring with them to the higher education system.

These questions allude to concerns that have also been expressed by Elegido (2009:17) in terms of indoctrination and self-selection, and can be investigated by means of pre- and post tests. The pre-test should take place prior to the start of a student's business studies, i.e. before he/she is exposed to reductive management theories and utility maximisation models, which could affect his/her reasoning and values. The posttest should take place after completion of the business qualification.

Another area of research that needs attention is the development, effectiveness, and assessment of existing green business education. Best practices in terms of green business education should be identified, and could serve as a basis for continually improving attempts at such education. Given the relative success of Science education in cultivating environmental citizenship among students, researchers also need to consider what could be learned from this discipline and transferred to business education.

\section{ACKNOWLEDGEMENTS}

The authors wish to express their sincere gratitude to philosopher and thought leader Prof Bert Olivier for his valuable comments and suggestions in the preparation of this article. They would also like to extend a special word of thanks to Ms Helen Allen, for language editing services, as well as the two reviewers who provided invaluable suggestions to improve this article.

\section{REFERENCES}

Armstrong, J. B. \& Impara, J. C. 1991. The impact of an environmental education program on knowledge and attitude. Fournal of Environmental Education, 22(4): 36-40.

Bernstein, B. B. 1981. Ecology and economics: complex systems in changing environments. Annual Review of Ecology and Systematics, 12: 309-330.

Berry, T. 1996. The university: its response to the ecological crisis. Paper delivered before the Divinity School and the University Committee on Environment at Harvard University, April 1. [Online]. Available: http://ecoethics.net/ops/berrybio.htm [Accessed 29 July 2010].

Cordano, M., Ellis, K. M. \& Scherer, R. F. 2003. Natural capitalists: increasing business students' environmental sensitivity. fournal of Management Education, 27(2): 144-157.

Cortese, A. D. 2003. The critical role of higher education in creating a sustainable future. Planning for Higher Education, March-May, 15-22.

Curry, P. 2007. Ecological ethics: an introduction. Massachusetts: Polity Press.

Darnall, N., Jolley, G. J. \& Handfield, R. 2006. Environmental management systems and green supply chain management: complements for sustainability? Business Strategy and the Environment, 18: 30-45. 
De Groot, J. I. M. \& Steg, L. 2008. Value orientations to explain beliefs related to environmental significant behaviour how to measure egoistic, altruistic, and biospheric value orientations. Environment and Behaviour, 40(3): 330-354.

Dietz, T., Fitzgerald, A. \& Swom, R. 2005. Environmental values. The Annual Review of Environment and Resources, 30: 335-372.

Dobson, A. 2007. Environmental citizenship: towards sustainable development. Sustainable Development, 15: 276-285.

Dobson, A. 2010. Environmental citizenship and pro-environmental behaviour. London: Sustainable Development Research Network.

Elegido, J. 2009. Business education and erosion of character. African fournal of Business Ethics, 4(1): 16-24.

Farrar, S. 2008. Lead the way in cutting carbon: MBAs in carbon management will become increasingly important as companies are forced to tackle climate change. Sunday Times, January 27. [Online]. Available: http:/business. timeonline.co.uk/tol/ business/related_reports/article3255969 [Accessed 12 August 2009].

Foster, J. B. \& Burkett, P. 2000. The dialectic of organic/inorganic relations: Marx and the Hegelian philosophy of nature. Organization Environment, 13: 403-425.

Gatersleben, B., Steg, L. \& Vlek, C. 2002. The measurement and determinants of environmentally significant consumer behaviour. Environment and behaviour, 34(4): 335-362.

Goshal, S. 2005. Bad management theories are destroying good management practices. Academy of Management Learning and Education, 4(1): 75-91.

Hawthorne, M. \& Alabaster, T. 1999. Citizen 2000: development of a model of environmental citizenship. Global Environmental Change, 9: 25-43.

Heisenberg, W. 1958. The representation of nature in contemporary physics. Daedalus, 87(3): 95-108.
Hsu, S.-J. 2004. The effects of an environmental education program on responsible environmental behavior and associated environmental literacy variables in Taiwanese college students. The fournal of Environmental Education, 35(2): 37-48.

Integrated Report Committee. 2011. King unveils world-first integrated reporting guidelines. Media release, 25 January. [Online]. Available: http://www.icsa. co.za/ documents/latestNews/IRCMediaReleaseF. pdf [Accessed 10 October 2011].

Intergovernmental Panel on Climate Change (IPCC) $4^{\text {th }}$ Assessment Report. (2007). [Online] Available: http://www.ipcc.ch/ publications_and_data/publications_and_ data_reports.htm\#1 [Accessed 1 November 2009].

Johnson, B. \& Manoli, C. C. 2008. Using Bogner and Wiseman's model of ecological values to measure the impact of an earth education programme on children's environmental perceptions. Environmental Education Research, 14(2): 115-127.

Keller, D. 2008. Book review: Patrick Curry, Ecological ethics: an introduction', Ethics and the Environment, 13(1): 1085-1100.

Kovel, J. 2002. The enemy of nature. The end of capitalism or the end of the world? New York: Zed Books.

Lesourd, J. B. \& Schilizzi, G. M. 2001. The environment in corporate management: new direction and economic insights. Cheltenham: Edward Elgar.

Loubser, C. P. (Ed). 2005. Environmental education: some South African perspectives. Pretoria: Van Schaik.

MacGregor, S. \& Szerszynski, B. 2003. Environmental citizenship and the administration of life. Paper presented at Citizenship and the Environment Workshop, Newcastle University, 4-6 September 2003.

Maduna, T. P. 2010. Environmental qualifications and modules offered at South African universities. Unpublished research report, Nelson Mandela Metropolitan University, Port Elizabeth. 
Millet, L. 2000. The Green Office Manual: a guide to responsible practice. $2^{\text {nd }}$ Edition. London: Earthscan Publications.

Minteer, B. A. \& Collins, J. P. (2008). From environmental to ecological ethics: toward a practical ethics for ecologists and conservationist. Science and Engineering, 14: 483-501.

MIT Sloan Management Review (MIT) \& The Boston Consulting Group (BCG). 2011. Sustainability: the 'embracers' seize advantage. [Online]. Available: http:// c0426007.cdn2.cloudfiles.rackspacecloud. com/MIT-SMR-BCG-sustainability-theembracers-seize-advantage-2011.pdf [Accessed 12 November 2011].

Monroe, M. C. 2003. Two avenues for encouraging conservation behaviours. Human Ecology Review, 10(2): 113-125.

Moody, G. L. \& Hartel, P. G. 2007. Evaluating an environmental literacy requirement chosen as a method to produce environmentally literate university students. International fournal of Sustainability in Higher Education, 8(3): 355-370.

Newton, L. H. 2005. Business ethics and the natural environment. Cornwell: Blackwell.

Onkila, T. J. 2008. Corporate argumentation for acceptability: reflections of environmental values and stakeholder relations in corporate environmental statements. Journal of Business Ethics, 87: 285-298.

Poortinga, W., Steg, L. \& Vlek, C. 2004. Values, environmental concern, and environmental behaviour: a study into household energy use. Environment and behaviour, 36(1): 70-93.

Roberts, B., Kivilu, M., \& Davids, Y. D.(Eds). 2010. South African social attitudes survey: reflections on the age of hope. $2^{\text {nd }}$ report. Cape Town: Human Sciences Research Council.
Romm, J. 2008. "Catastrophic" $5-7^{\circ} \mathrm{C}$ warming by 2100 on current emissions path. Hadley Center, [Online]. Available: http:// climateprogress.org/2008/12/21/hadleystudy-warns-of-catastrophic-5\%C2\%B0cwarming-by-2100-on-current-emissionspath/ [Accessed 5 January 2010].

Sadgrove, K. 1997. A to Z of Corporate Environmental Management. London: Earthscan Publications.

Sammalisto, K. \& Arvidsson, K. 2005. Environmental management in Swedish higher education: directives, driving forces, hindrances, environmental aspects and environmental co-ordination in Swedish universities. International fournal of Sustainability in Higher Education, 6(1): 18-35.

Sherren, K. 2006. Reflections on sustainability in Australian University coursework programs. International fournal of Sustainability in Higher Education, 7(4): 400-413.

Short, P. C. 2010. Responsible environmental action: its role and status in environmental education and environmental quality. The Journal of Environmental Education, 41(1): 7-21.

South African Department of Environmental Affairs. 2010. Environmental sector skills plan for South Africa: a systems approach to human capacity development and sector skills planning. Pretoria: Department of Environmental Affairs.

State of the environment. 2010. Department of Environmental Affairs and Tourism. [Online]. Available: http://soer.deat.gov. za/519.html [Accessed 1 September 2010].

The Belgrade Charter. (1975). [Online]. Available: http://www.envir.ee/orb.aw/class= file/action $=$ preview $/$ id $=1011467 /$ The\%2BBelgrade\%2BCharter.pdf [Accessed 17 May 2010].

The new bottom line. 2010. Financial Mail - special report: The green report. 15 October, 6-8. 
The Tbilisi Declaration. 1977. Intergovernmental conference on environmental education, October 14-26. [Online]. Available: http:// www.cnr.uidaho.edu/css487/The_Tbilisi_ Declaration.pdf [Accessed 26 May 2010].

Thomas, I. 2004. Sustainability in tertiary curricula: what is stopping it happening? International fournal of Sustainability in Higher Education, 5(1): 33-47.

Thompson, E. R. \& Phua, F. T. T. 2005. Reliability among senior managers of the MarloweCrowne short-form social desirability scale. Journal of Business and Psychology, 19(4): 541-554.

Uhl, C. \& Anderson, A. 2001. Green destiny: universities leading the way to a sustainable future. Bioscience, 51(1): 36-42.

Venkataraman, B. 2008. Why environmental education? Environment Magazine, 50(5): 8-10.

World Energy Outlook. 2008. International Energy Agency. [Online] Available: www.iea.org [Accessed 5 January 2010].

World Wildlife Fund (WWF) Living Planet Report. (2008). [Online]. Available: http:// www.footprintnetwork.org/download. php?id=505 [Accessed 21 August 2011].
Wright, T. S. A. 2002. Definitions and frameworks for environmental sustainability in higher education. International fournal of Sustainability in Higher Education, 3(3): 203-220.

Zietsman, S. \& Pretorius, R. W. 2006. Learning programmes for environmental sustainability: a different approach to curriculum design. South African fournal of Higher Education, 20(5): 691-702.

\section{End notes}

1. It should be noted that, although climate change is referred to in many cases in this research, the researcher is aware that climate change is only one of the environmental problems facing humanity at present. Other (related) environmental problems include global warming, deforestation, water and air pollution, soil erosion, etc. Climate change is referred to because it is directly or indirectly related to a host of other environmental problems.

2. The IPCC is in the process of compiling another report, which will be made available in $2013 / 2014$. 